\title{
Controversion of Zonation Application to New Students in Bali Province
}

\author{
I Nyoman Suandika ${ }^{1}$, Komang Edy Dharma Saputra ${ }^{2}$ \\ \{pakden278@gmail.com¹, Edydharmasaputra@Gamial.com ${ }^{2}$ \} \\ Faculty Of Law, Mahendradatta University, Bali ${ }^{1,2}$
}

\begin{abstract}
Education is often the center of attention in Indonesia because the state has an obligation to educate the Indonesian people. An effort to improve and equalize education in Indonesia is the application of a zoning system in the process of admitting new students as outlined in the Education and Culture Regulation Number 14 of 2018. This regulation has drawn controversy in various regions including Bali Province. The main factor for controversy over the application of zoning is the high level of disputes between favorite and non-favorite schools, and the efforts made by the government are to conduct intensive socialization that can reach all lines and levels of society to raise awareness and participate in supporting zoning policies.
\end{abstract}

Keywords: Education, Zoning, Controversy

\section{Introduction}

In Indonesia, education is one of the things that is often of concern to the public because education is one of the most important things to improve the intelligence of the nation's life in Indonesia. Basically, according to the 1945 Constitution of the Republic of Indonesia in article 1 paragraph (3) it emphasizes that the state of Indonesia is a state of law which implies that every action of the state and citizens must be based on and based on law [1], [2]. Furthermore, in the field of education, as emphasized in the preamble of the 1945 Constitution of the Republic of Indonesia, the state has an obligation to educate the Indonesian nation. In educating the nation's life in Indonesia, it always involves the State and the private sector so that in Indonesia there are many public schools and private schools which are increasingly developing and experiencing improvements starting from Elementary School, Junior High School, Vocational High School, Senior High School, even to the tertiary institutions because the two agencies both have the right to participate in the intellectual life of the nation and state. In the education sector, one of the efforts made by the government to increase and equalize the quality of education in Indonesia is the application of a zoning system to the process of admitting new students. Zoning based on the Indonesian dictionary, explains that zoning is the division or division of an area into several parts, according to management functions and objectives [3]. Zoning in Indonesia is still ongoing and there are some parents or guardians who accept it and some feel disadvantaged.

The provisions of the zoning system are contained in the Regulation of the Minister of Education and Culture Number 14 of 2018 concerning the Admission of New Students in Kindergartens, Elementary Schools, Junior High Schools, Senior High Schools, Vocational High Schools, or other equivalent forms [4]. With the implementation of these regulations in Indonesia, it seems that not 100 percent of the parents or guardians of students accept these rules. So that it reaps controversy, because with the enactment there are those who benefit and 
some feel disadvantaged, including Bali as a province in the unitary state of the Republic of Indonesia, some parents or guardians of students are still concerned about this. So that often when approaching the new academic year the zoning system becomes hot news in various media, both print media, online media, and voice media. The problem is, what is the attitude of the community with the application of zoning in the acceptance of new students with the issuance of Minister of Education and Culture Regulation Number 14 of 2018 in the Province of Bali, and how is the effort made by the government to overcome zoning problems in the Province of Bali.

\section{Research Method}

The writing method is the most important thing in research activities to obtain data then compile, process, and analyze as well as legal research genius follows the character of law science in a broad sense, and species species follows the scientific character of law in accordance with the field of specialization in legal science [5]. This research uses empirical legal research, namely research conducted by processing data obtained in the field which is supported by literature. The data source used is primary data, namely data obtained directly from the object of research, namely through observation, interviews from informants. Secondary data is data obtained through library research by browsing books, journals, articles, and others. Tertiary data is material that provides instructions or explanations for primary data and secondary data such as the Indonesian dictionary.

\section{Results and Discussion}

\subsection{Public Attitude With the Implementation of Zoning in the Admission of New Students With the Issuance of Permendikbud Number 14 of 2018 in Bali Province}

The 1945 Constitution of the Republic of Indonesia in article 31 paragraph (1) clearly states that every citizen has the right to obtain and the government is obliged to finance it, Continued with paragraph (3) states that the government strives and implements a national education system that enhances faith and piety as well as noble morals in educating the nation's life as regulated by law (the National Education System). This matter emphasizes that the government is obliged and responsible to organize and empower an education for every citizen in order to enlighten the life of the nation, which is one of the goals of the Indonesian state.

This provision is strengthened by the promulgation of Law number 20 of 2003 concerning the National Education System as emphasized in Article 5 paragraph (1) which states that every citizen has the same right to obtain quality education [6]. This is continued by the affirmation of Article 6 paragraph (1) which states that every citizen aged 7-15 years is obliged to attend basic education. With this provision, in terms of admission of new students who will take basic education in 2018 the Ministry of Education and Culture of the Republic of Indonesia issued a Regulation of the Minister of Education and Culture Number 14 of 2018 concerning the Admission of New Students [7]. However, there is one thing that is of concern, 
namely the implementation of the school zoning system. Minister of Education and Culture Muhadjir Efendy emphasized that this zoning system was carried out for the sake of equitable education in Indonesia. As for what is meant by the zoning regulations stated in article 16 of the Regulation of the Minister of Education and Culture Number 14 of 2018, namely schools must accept new students who are domiciled in the radius closest to the school as seen based on the address on the family card issued no later than 6 months before the acceptance period New Learners. Then this zoning regulation was stipulated for elementary schools, junior high schools and senior high schools, while for vocational high schools, the zoning regulations were exempted. However, the zoning application seems to have generated controversy in the community. Based on the results of the research, the attitude of the community with the application of the zoning system is that from the data obtained there are those who agree and disagree with the application of the zoning system in the admission of new students. As stated by I Wayan Winarsa that he agreed with the implementation of the zoning system because with the implementation of the zoning system it would be easier to find a school because it was determined from the beginning where the school was and would affect costs in the sense that it would make it easier to drop off and pick up because of the closer distance. Besides that, another view was also conveyed by I wayan Putu Budiata who stated that he did not agree with the implementation of the zoning system in the admission of new students because he could not choose the school he wanted. From the interviews conducted, although there are those who agree and disagree with the implementation of the zoning system, the positive and negative sides of the zoning system are as follows:

1. The positive impacts are as follows:

a) Equity among schools in terms of achievement and number of new student admissions each year.

b) Prioritizing local students in the acceptance of new students

2. The negative impacts of the implementation of the zoning system in the admission of new students are:

a) Cannot go to school as you wish

b) Aggressive learning decreases and children's achievement is neglected because it has been determined by the region.

\subsection{Efforts Made by the Government of the Province of Bali in Overcoming Problems in the Application of Zoning in the Admission of New Students}

The acceptance of new students is one of the things that often creates problems in social life, especially with the application of a zoning system in the admission of new students in Bali province because not 100 percent of parents know and understand in detail about the application of zoning in the admission of new students. To minimize these problems, the efforts made by the provincial government of Bali are in accordance with the results of the research carried out, namely through several efforts including:

1) Socialization, Socialization of zoning is one of the efforts made by the provincial government of Bali with the aim that all people understand and know for sure about the application of zoning in the admission of new students.

2) Collaboration with schools, the cooperation in question is the school helping and giving instructions to prospective new students if they do not understand, or do not understand the technicality of registration so that it can be ascertained that the person concerned has been registered as a prospective new student because it is assisted by the school. 


\section{Conclusion}

From the discussion above, two conclusions can be drawn including the following:

1) The attitude of the community with the implementation of the zoning system in the admission of new students is that there are those who agree with the reason that with the implementation of the zoning system it will be easier to find schools because it is determined by the region and some do not agree because prospective new students find it difficult to find schools that are desired.

2) Efforts made by the provincial government of Bali to minimize the problem of zoning application in the admission of new students are by conducting socialization and working with schools.

\section{References}

[1] Indonesia, R.:Undang-Undang Dasar Negara Republik Indonesia Tahun 1945. Sekretariat Jenderal MPR RI, (2002).

[2] Kurniawan, L. J. and Lutfi, M.:Perihal negara, hukum \& kebijakan publik: perspektif politik kesejahteraan yang berbasis kearifan lokal, pro civil society dan gender. Setara Press, (2011).

[3] Suharso: Kamus Besar Bahasa Indonesia. Semarang: CV Widya Karya, Semarang, (2011).

[4]: Peraturan Menteri Pendidikan dan Kebudayaan Nomor 14 Tahun 2018 tentang Penerimaan Peserta Didik Baru (Berita Negara Republik Indonesia Tahun 2018 Nomor 605). (2018).

[5] Qamar, N. et al.:Metode Penelitian Hukum (Legal Research Methods). CV. Social Politic Genius (SIGn), (2017).

[6] Nasional, D. P.:Undang-Undang Nomor 20 Tahun 2003 Tentang Sistem Pendidikan Nasional, vol. 33. (2003).

[7] Khadowmi, E. R.: Implementasi Kebijakan Sistem Zonasi Terhadap Proses Penerimaan Peserta Didik Baru Kabupaten Lampung Tengah, (2019). 